\title{
Organ Preservation: Current Concepts and New Strategies for the Next Decade
}

\author{
Edgardo E. Guibert ${ }^{a *}$ Alexander Y. Petrenko ${ }^{\text {b* }}$ Cecilia L. Balaban ${ }^{a *} \quad$ Alexander Y. Somov $^{\text {* }}$ \\ Joaquín V. Rodriguez ${ }^{\text {a* }}$ Barry J. Fuller ${ }^{\text {c* }}$ \\ ${ }^{a}$ Centro Binacional (Argentina-Italia) de Investigaciones en Criobiología Clínica y Aplicada (CAIC), \\ Universidad Nacional de Rosario, Argentina \\ ${ }^{\mathrm{b}}$ Department of Cryobiochemistry, Institute for Problems of Cryobiology and Cryomedicine, \\ Ukraine Academy of Sciences, Kharkov, Ukraine \\ ${ }^{c}$ Cell, Tissue and Organ Preservation Unit, Department of Surgery \& Liver Transplant Unit, UCL Medical School, \\ Royal Free Hospital Campus, London, UK
}

\section{Keywords}

Biopreservation - Storage · Organ .

Transplantation · Kidney · Liver · Heart · Lung ·

Pancreas - Small bowel · Hypoxia - Hypothermia .

Perfusion - Metabolism - UW solution - Collins solution .

Bretschneider's solution

\section{Summary}

Organ transplantation has developed over the past 50 years to reach the sophisticated and integrated clinical service of today through several advances in science. One of the most important of these has been the ability to apply organ preservation protocols to deliver donor organs of high quality, via a network of organ exchange to match the most suitable recipient patient to the best available organ, capable of rapid resumption of life-sustaining function in the recipient patient. This has only been possible by amassing a good understanding of the potential effects of hypoxic injury on donated organs, and how to prevent these by applying organ preservation. This review sets out the history of organ preservation, how applications of hypothermia have become central to the process, and what the current status is for the range of solid organs commonly transplanted. The science of organ preservation is constantly being updated with new knowledge and ideas, and the review also discusses what innovations are coming close to clinical reality to meet the growing demands for high quality organs in transplantation over the next few years.

*UNESCO Chair in Cryobiology

\author{
Schlüsselwörter \\ Biologische Konservierung · Lagerung · Organ · \\ Transplantation · Niere · Leber · Herz · Lunge · \\ Bauchspeicheldrüse · Dünndarm · Hypoxie - Hypothermie . \\ Durchblutung · Stoffwechsel · UW-Lösung · Collins-Lösung · \\ Bretschneider-Lösung
}

\section{Zusammenfassung}

Die Organtransplantation hat sich in den vergangenen 50 Jahren aufgrund wissenschaftlicher Fortschritte zu einem hochentwickelten und integralen Bestandteil klinischer Therapieoptionen herausgebildet. Am wichtigsten davon war, mittels geeigneter Organkonservierungsprotokolle Spenderorgane von hoher Qualität zur Verfügung stellen und über ein Netzwerk austauschen zu können, um so den am besten geeigneten Patienten mit dem besten verfügbaren Organ versorgen zu können, wodurch eine schnelle Wiederherstellung der lebenserhaltenden Funktionen beim Organempfänger erreicht werden konnte. Dies war nur möglich, indem ein Verständnis der möglichen Effekte des hypoxischen Schadens und dessen Vermeidung bei den gespendeten Organen entwickelt wurde. Die vorliegende Übersichtsarbeit befasst sich zunächst mit der Geschichte der Organkonservierung, wie die Anwendung der Hypothermie ins Zentrum des Prozesses gerückt ist und wie sich die Situation für die üblicherweise transplantierten soliden Organe darstellt. Die Organkonservierung als Wissenschaft befindet sich in einem stetigen Erneuerungsprozess anhand neuer Erkenntnisse und Ideen, deshalb diskutiert diese Übersichtsarbeit auch Neuerungen, die kurz vor einer klinischen Umsetzung stehen, um dem wachsenden Bedarf an hochwertigen Organen zur Transplantation in den kommenden Jahren gerecht werden zu können.

\begin{tabular}{ll}
\hline KARGER & ( ) 2011 S. Karger GmbH, Freiburg \\
Fax +49 761 4520714 & Accessible online at: \\
Information@Karger.de & www.karger.com/tmh \\
www.karger.com &
\end{tabular}




\section{Introduction}

Organ transplantation has been one of the most significant advances in medicine in the latter half of the 20th century and remains in many cases the only effective therapy for end-stage organ failure. The supply of organs of high quality and efficacy has always been one step of extreme importance in the overall multi-disciplinary approach to transplantation, and was identified as such early on in service development. Organ preservation has been described as 'the supply line for organ transplantation' [1] and in a logistical sense, 'preservation' buys 'time', which is essential to organise staff and facilities, transport organs, and perform necessary laboratory tests. The ability to use the powerful effects of cooling to slow biological deterioration in organs removed from their normal physiological environment has permitted the development of modern transplant services. However, low temperatures have a multitude of effects (both supportive and destructive) on mammalian cell biology which have required careful investigation to permit us to apply cold during organ preservation [2], and this has been the history of the development of techniques which are currently in use world-wide. In this review, we set out what we have learnt during the past 40 years since organ preservation was first applied in the clinic, the basis of the current practices, and the challenges and opportunities for the future as demands for organ transplantation increase.

\section{History of Organ Preservation for Transplantation}

By the start of clinical transplantation in the 1960s, there was already a significant knowledge base from physiologists and anatomists about requirements to keep organs viable and functioning outside the body. The development of reliable perfusion pumps allowed the use of artificial perfusion circuits to study the physiology of organ function [3]. These kinds of studies were further facilitated by replacement of blood by synthetic perfusates - solutions of electrolytes, solutes, and vitamins $[4,5]$. At the same time, use of lower temperatures to alter metabolism during perfusion provided an additional powerful tool [6]. Specific information on use of low temperatures to avoid organ damage during surgery was also gradually being amassed [7]. The team led by Calne performed one of the earliest investigations into the relative merits of cooling kidneys by simple surface cooling or by cooling via the whole vascular bed with perfusion of the renal artery with cooled heparinised blood [8]. These authors concluded that vascular flush perfusion was the more efficient method of cooling the organ mass. However, use of chilled heparinised or diluted blood still caused many problems such as vascular stasis on re-implantation of the graft. Therefore, it was recognised that successful preservation would require the development of new, acellular solutions, which ushered in the first era of organ preservation research.
The pioneering work by Collins and his colleagues [9] led to the design of an acellular solution which mimicked, in a simple fashion, the intracellular electrolyte balance of the mammalian cells, and was the first notable attempt to advance organ preservation based on an understanding of the ongoing changes in cells during cooling. The resultant solutions (termed Collins solutions) provided were a significant improvement in reliable preservation and were used routinely in transplant centres across the world for almost two decades. These solutions permitted successful renal preservation for 24-36 h, which was long enough to allow tissue matching and sharing of organs between transplant centres. Alongside these approaches, the proponents of continuous hypothermic perfusion continued to develop their methods for oxygenated low temperature, low pressure perfusion $[10,11]$. However, due to logistical considerations and reliability of the perfusion equipment available at that time, static flush cooling followed by ice storage became the most widely used preservation method. With the expansion of transplantation as a clinical therapy from the 1980s onwards, methods of multiple organ procurement and preservation were necessitated. In this approach, kidneys, liver, pancreas, heart, and lungs or various combinations of these organs could be removed without jeopardizing any of the individual organs. This led to the adoption of so-called 'flexible techniques' for organ procurement [12] in which all donor organs to be procured are cooled in situ, rapidly and simultaneously, removed in a bloodless field, and further dissected and packaged on a back table.

Over recent years, the continuing shortage of donor organs for transplantation and change in transplant donor demographics have maintained the pressure to achieve the optimal and efficacious approach to organ preservation, which is the driver for ongoing research into organ preservation.

\section{Use of Cooling and What Cooling Does}

The stages in transplantation, which range from retrieving the organ from the donor, preserving it (usually by cooling in specific solution) throughout to its implantation in the recipient (re-perfusion), are accompanied by a myriad of changes, which are complex and multi-factorial (molecular, cell and tissue changes, produced during the required anoxia period of the surgery and for the duration of the cold storage), and they are manifested in the transplant. The physiopathological processes responsible for transplant injuries are defined as ischaemia/re-perfusion injury (IRI) in organ transplantation. Although this fundamental requirement, the chilling of organs, has harmful repercussions on the tissues due to oxidative stress (production of reactive oxygen species) and inflammation (cytokine production), which are probably responsible for the exacerbation and, above all, persistence of this condition, it is one of the most widespread methods to preserve organs for transplant. Significant structural changes in the 
cytoskeleton result in dislocation of the endothelial cells. However, one thing is clear: Good organ preservation is a major determinant of graft outcome after re-vascularisation. While the use of preservation solutions significantly improved organ preservation, it merely slows down extracorporeal ischaemic and hypoxic damage rather than preventing cellular injury. This results in primary graft dysfunction, which remains a major clinical problem.

Cooling is the first line of defense against hypoxic injury. Cooling is necessary to reduce cellular metabolism and the requirements for oxygen to prevent tissue injury. A great deal of information has been accumulated over the past centuries on the effects of cold on physiology and biochemistry [2]. In evolutionary terms, some animal systems (such as hibernatory mammals) have become adapted to cold exposure, which permits exploitation of environmental niches in cold parts of the planet. In nature, several key criteria have evolved which enable cold, oxygen-limited survival, and amongst these the major ones which can be linked with organ preservation for transplantation are: i) a global metabolic rate suppression, ii) metabolic pathways capable of sustaining and/or delivering minimal essential energy supplies (ATP and phenotypic alterations to prioritise ATP use), and iii) enhancement of defense mechanisms (at the molecular and cellular levels) to allow cohesive return to normal metabolism during arousal. These basic evolutionary links across animal physiology may be one reason why human organs can tolerate cooling to some extent. However, human organs do not have the capacity to replicate all of the genotypic and phenotypic changes made by cold-tolerant animals, which is why cooling has limitations on success, with only short exposures being tolerated. In metabolically active cells, ATP levels are maintained constantly. However, at $4{ }^{\circ} \mathrm{C}$, there are some metabolic rates remaining. As regards the cells, several metabolic pathways are affected: Inhibition of the $\mathrm{Na}^{+} / \mathrm{K}^{+}$ATPase causes cell oedema, rapid depletion in ATP reserves, and a corresponding increase in ADP levels, and this depletion of ATP leads to the degradation of adenosine causing accumulation of hypoxanthine and xanthine oxidase. Cell membrane depolarisation also occurs very early in the cascade leading to a breakdown of ion homeostasis, and a interplay of other intracellular and membraneassociated events that eventually culminate in cell death by either apoptosis or necrosis [13].

There are problems associated with calcium movements and an increment in anaerobic glycolysis, which is mainly responsible for intracellular acidosis. An increase in the cytosolic $\mathrm{Ca}^{2+}$ concentration is thought to result from the inhibition of the endoplasmic reticulum $\mathrm{Ca}^{2+}$ ATPase by ATP deficiency, the inhibition of the $\mathrm{Na}^{+} / \mathrm{Ca}^{2+}$ antiporter by increased cytosolic sodium concentrations (and thus decreased sodium gradients), and the function of the $\mathrm{Na}^{+} / \mathrm{Ca}^{2+}$ antiporter in 'reverse mode', by transporting calcium 'in' and sodium 'out'. This triggers mitochondrial dysfunction by disrupting its membrane permeability, allowing the accumulation of cal- cium, sodium and water within the cell. The subsequent membrane injury and protein degradation have long been considered to be the decisive processes toward lethal cell injury [14]. The extent of overall preservation injury is directly related to the severity of IRI after transplantation. [15]. For example, in the liver, among hepatocellular perturbations, dysfunction in liver cell volume, bile secretion, drug metabolism, and mitochondrial function have been reported as a result of cold preservation/warm re-oxygenation [16]. As a variant, liver endothelial cells did not show the classic mitochondrial permeability transition associated with mitochondrial swelling but rather mitochondrial ultra-condensation, another mitochondrial alteration that has been shown to be involved in diverse apoptotic pathways. However, mitochondrial fragmentation was fully reversible and appears to be largely a stress phenomenon that is not critically involved in cold-induced injury [14].

The length of time that an organ such as kidney can be stored depends on both cooling to diminish metabolic activity and thus oxygen requirements, and on use of fluids designed to preserve the intracellular milieu in the absence of a $\mathrm{Na}^{+} / \mathrm{K}^{+}$ pump [17]. The exact mechanisms underlying these functional disorders are still not understood, but the involvement of intracellular $\mathrm{Ca}^{2+}$ has been proposed [18]. Accumulating evidence suggest perturbations at the endoplasmic reticulum as novel sub-cellular effectors that are possibly involved in promotion of cell death in various pathologies, including the pathophysiology of organ preservation [19].

Oxygen radicals appear to be involved in the microvascular and parenchymal cell injury in various pathologic disorders associated with organ preservation. Studies indicate that oxygen radicals increase microvascular permeability by creating large leakage sites predominantly in the small venules. The highly reactive hydroxyl radical appears to be responsible for the microvascular alterations associated with oxygen radical production. There is considerable indirect evidence that oxygen radicals are involved in the pathogenesis of circulatory shock [20]. Unlike many other types of cell injury mediated by reactive oxygen species, cold-induced cell injury (whether occurring in the cold itself or during re-warming) does not appear to be triggered by an enhanced release of the reactive oxygen species: superoxide anion radical $\left(\mathrm{O}_{2}^{-}\right)$or hydrogen peroxide $\left(\mathrm{H}_{2} \mathrm{O}_{2}\right)$, but by an increase in the cellular chelatable, redox-active iron pool that converts these species of low reactivity (and molecular oxygen) into highly reactive species, such as the hydroxyl radical or iron-oxygen species [14]. Depending on the residual ATP level, which is related to the duration of the ischaemia, this dysfunction will manifest as apoptosis or necrosis. The ATP concentration therefore acts as a 'switch' between these two types of cell death. When the transition of mitochondrial membrane permeability is accompanied by ATP depletion (prolonged ischaemia), the apoptotic signal is blocked and necrosis develops. The few molecular studies of gene expression during ischaemia/re-perfusion period carried out to date focus on the re-perfusion phase. 
They have highlighted the role of certain signalling pathways such as pro- or anti-apoptotic pathways like Bcl-2 and Bag-1, two regulatory genes controlling apoptosis [17] in reducing hypoxic cell damage. There is also a possible effect on the haeme oxygenase pathway (a member of the stress protein family) [21] and on the transcription factor HIF (hypoxia inducible factor) pathway [22]. There remain many hurdles to overcome before such evidence can be translated to improved preservation methods in clinical application, for example in gene therapy including the nature of the transfection agent and the timing of gene induction, but these will undoubtedly become the centre of attention in the near future.

By using proteomic technology, recently published reports like that of Strey et al. [23] identified several proteins implicated in the context of cellular adaptation mechanism in response to IRI and probed whether these molecular clues might explain the phenotypic changes expressed in the cells. Of course, further studies are needed to elucidate the relevance of the observed changes in the clinical setting.

Maintaining the viability of the transplant during its ischaemic transfer from donor to recipient is mainly based on hypothermia, which is deliberately applied to reduce metabolic activity. Tolerated periods of cold ischaemia vary depending on the organ: $24 \mathrm{~h}$ for the kidney, $12-15 \mathrm{~h}$ for the liver, a maximum of $8 \mathrm{~h}$ for the lung, and $6 \mathrm{~h}$ for the heart. Prolonged cold ischaemia is an independent risk factor for the non-functioning or dysfunction of the transplant.

\section{Approaches to Organ Preservation}

Clinical organ transplantation has moved forward from an experimental procedure 50 years ago to the current treatment of choice for patients with end-stage organ disease where patient and graft survival rates exceed $90 \%$ per year [13]. With the shortage of organs available for transplant, there is an extreme necessity for a better use of all available organs, and organ preservation is a crucial step in the transplant process. The main goal in organ preservation is to maintain function of the organ and tissue during storage so that the graft will function at re-perfusion.

There are currently two approaches of preservation for most transplantable organs: static or dynamic. Simple static cold storage (SCS) is the main method for static storage, while hypothermic machine perfusion (HMP) and other perfusionbased methods such as normothermic machine perfusion and oxygen persufflation comprise the methods for dynamic preservation. Of these 4 methods, only SCS and HMP are currently approved clinically for kidneys, and only SCS for livers, lungs, pancreas, or heart. The remaining methods are in various stages of pre-clinical and early clinical studies [24]. SCS relies on the effects of cooling alone, supplemented by the use of special preservation solutions which are aimed at modifying in a positive way the inevitable cellular molecular changes
[25]. In contrast, HMP depends on activating residual metabolism, largely dependent on energy generation which in mammalian systems is synonymous with a need for oxygen supply for aerobic metabolism delivered by vascular perfusion [26]. Both preservation modalities are preceded by the donor procurement phase, where access to the required organs is surgically achieved by introducing chilled solutions in sufficient volumes (clinically this requires in the region of 4-6 1 of chilled solutions) into the major vascular channels (the abdominal or thoracic aorta, portal vein or pulmonary artery depending on the organ of interest) to wash out the blood and achieve moderate cooling $\left(10-15^{\circ} \mathrm{C}\right)$ before final removal from the body. These methods have been developed from the so-called flexible techniques described by Starzl and colleagues [27]. The organs can then be removed from the body and transferred to sterile back-tables where the final introduction of the desired preservation solutions can be achieved. For SCS, the organs can then be placed in fresh sterile solutions, double-bagged, and buried in melting ice in transport containers for dispatch to the recipient transplant centre [25].

The use of organs from marginal donors, such as the non heart-beating donor (NHBD), has become an important means for expansion of the donor organ pool. For these organs, the preservation method applied is of even greater importance than for heart-beating donor organs. This has led to a renewed interest in HMP as a preservation method for both thoracic and abdominal organs. Recent studies have demonstrated advantages of pulsatile perfusion over SCS preservation for kidney transplantation. Machine perfusion systems continuously pump cold preservation solution through the kidney. The solution provides nutrients and sometimes oxygen, carries away toxic metabolites, and delivers buffers which absorb the build-up of lactic acid [13]. Machine perfusion requires dissection of the artery to attach the kidney to the machine and further dissection of the kidney to make the seal watertight. This preparation process takes longer than SCS, but may encourage assessment of the kidney for abnormalities. HMP reduced the incidence of delayed graft function in the kidneys obtained from the most common types of deceased donors. In addition, machine perfusion reduced the duration of delayed graft function if it occurred. Machine-perfused renal allografts had a lower risk of graft failure in the first year after transplantation, and, as a result, these kidneys showed an improved 1-year graft survival as compared with kidneys preserved by SCS [28].

What are the down-sides of preserving deceased-donor kidneys using machine perfusion? SCS is a technically simpler and cheaper than HMP (which in the USA costs approximately USD 3,000.- more than SCS). However, costs over the life-time of a transplant could be lower with HMP owing to a lower incidence of delayed graft function (which results in a decreased likelihood of dialysis), shorter hospital stays, and better graft survival rates [29].

To date, the majority of donor livers used for transplantation originate from brain-dead donors. Livers from marginal or 
Table 1. Composition of preservation solutions ${ }^{\mathrm{a}}$

\begin{tabular}{|c|c|c|c|c|c|}
\hline Component & Euro-Collins & UW (Viaspan ${ }^{\circledR}$ ) & Celsior $^{\circledR}$ & Custodiol $^{\circledR}$ & IGL-1 ${ }^{\circledR}$ \\
\hline $\mathrm{NaCl}$ & 10.0 & - & - & 15.0 & - \\
\hline $\mathrm{KCl}$ & 108.0 & - & 15.0 & 9.0 & - \\
\hline Potassium hydrogen 2-ketoglutarate & - & - & - & 1.0 & - \\
\hline Lactobionate & - & 100.0 & 80.0 & - & 100.0 \\
\hline PEG 35,000 & - & - & - & - & 0.03 \\
\hline $\mathrm{MgCl}_{2} 6 \mathrm{H}_{2} \mathrm{O}$ & - & - & 13.0 & 4.0 & - \\
\hline $\mathrm{NaCO}_{3} \mathrm{H}$ & 10.0 & - & - & - & - \\
\hline $\mathrm{NaOH}$ & - & 25.0 & 100 & - & $*$ \\
\hline $\mathrm{KOH}$ & - & 100.0 & - & - & - \\
\hline $\mathrm{MgSO}_{4}$ & - & 5.0 & - & 5.0 & 5.0 \\
\hline Glutamic acid & - & - & 20.0 & - & - \\
\hline Glutathione & - & 3.0 & 3.0 & - & 3.0 \\
\hline Glucose & 180.0 & - & - & - & - \\
\hline Histidine $\mathrm{HCl} \mathrm{H}_{2} \mathrm{O}$ & - & - & 30.0 & 18.0 & - \\
\hline Histidine & - & - & - & 180.0 & - \\
\hline Adenosine & - & 5.0 & - & - & 5.0 \\
\hline Allopurinol & - & 1.0 & - & - & 1.0 \\
\hline Tryptophan & - & - & - & 2.0 & - \\
\hline Mannitol & - & - & 60.0 & 30.0 & - \\
\hline Raffinose & - & 30.0 & - & - & 30.0 \\
\hline $\mathrm{CaCl}_{2} 2 \mathrm{H}_{2} \mathrm{O}$ & - & - & 0.25 & 0,015 & 0.03 \\
\hline Pentafraction (HES), g/l & - & 50.0 & - & - & - \\
\hline Phosphate & 60.0 & 25.0 & - & - & 25.0 \\
\hline Insulin, U/1 & - & 40.0 & - & - & - \\
\hline Dexamethasone, mg/l & - & 16.0 & - & - & - \\
\hline Penicilin G, UI/1 & - & 200,000 & - & - & - \\
\hline $\mathrm{Na}^{+}$ & 10.0 & 25.0 & 100.0 & 15.0 & 125.0 \\
\hline $\mathrm{K}^{+}$ & 115.0 & 125.0 & 15.0 & 10.0 & 30.0 \\
\hline $\mathrm{pH}$ & $7.30\left(0^{\circ} \mathrm{C}\right)$ & $7.40\left(25^{\circ} \mathrm{C}\right)$ & $7.30\left(20^{\circ} \mathrm{C}\right)$ & $7.02-7.20\left(25^{\circ} \mathrm{C}\right)$ & $7.40\left(25^{\circ} \mathrm{C}\right)$ \\
\hline Osmolality, mosmol/kg $\mathrm{H}_{2} \mathrm{O}$ & 340 & 320 & $242-368$ & 310 & 320 \\
\hline
\end{tabular}

NHBDs are presumed to have a poorer quality and are rarely used for transplantation because of non-expected decreased organ viability and associated technical complications. To overcome the present shortage of donors by expansion of the existing donor pool and possibly lengthening of the storage time HMP as a dynamic preservation method is an alternative [30]. Grafts from NHBDs are thought to be best preserved by HMP.

The hypothermic perfusion system opens the possibility to apply pharmacological manoeuvres on the hypothermically perfused organs. This procedure is designed to overcome or to revert the injuries due to the non-controlled warm ischaemic period or the hypothermia itself. In this way, a major point to be investigated is the role of oxygenation during HMP. Various settings of HMP have been applied, with added oxygen or not, pulsatile or non-pulsatile flow, various pressures and perfusion flows, and various preservation solutions [31]. The ideal HMP setting has not yet been really defined, but one key question that has remained is whether or not oxygenation of the preservation solution is a requirement for effective preservation and maintenance of organ viability and function. In this context, there are particular interests to delineate the roles of oxygenation, energetic substrates, and metabolic changes during the hypothermic perfusion. A potential risk of oxygenated HMP is the exposure to continuous oxygenation at low temperatures. Indications for the role of ROS under oxygenation in the low temperature condition have come from studies with isolated cell suspension [32]. Controversy exists concerning the role of oxygenation during HMP. Data obtained from hypothermically perfused rat livers has shown oxygen consumption of about a $5 \%$ of that found at $37{ }^{\circ} \mathrm{C}$. On the other hand, a recent paper from Luer et al. [33] has shown that, when during HMP the preservation solution was equilibrated with $100 \%$ oxygen, the efficiency of HMP was markedly increased by the additional aeration of the perfusate.

Safe cold ischaemic time for clinical heart preservation is limited to 4-6 h using principally SCS methods. Hypothermic perfusion of hearts facilitates early post-storage contractile capacity due to uniform myocardium cooling, constant washout of metabolic waste products during ischaemia, and continuous supplementation of the needed metabolic substances. 
Currently, no device for machine perfusion of human allograft hearts is FDA-approved for clinical use. Key parameters for optimum preservation such as perfusate composition and temperature, perfusion pressure and flow rate still need to be determined, with myocardial oedema being one of the highest risks of this technique. Nevertheless, several devices and techniques are currently under investigation [13].

In reality, it may be too simplistic to attempt to directly compare the merits of SCS and HMP, normothermic perfusion or persufflation, or the potential benefits of the different media to be used in each (blood, synthetic crytalloid solutions or aqueous solutions with artificial oxygen carriers), and to expect to identify the best approach. Each of the different approaches may be more appropriate for particular donor circumstances or types of donor organs. Thus in future there may be several options in organ preservation strategies which can be matched to necessity, which is another good reason for continued research into organ preservation.

\section{Development of Preservation Solutions}

Redox changes are central to organ hypoxia during preservation. It is known that the redox conversion in tissues is associated with the transfer of electrons between molecules and ions with a simultaneous exchange of their charges. Since losslattachment of an electron is simultaneous, the process of intermolecular electron transfer is called redox reaction. At a constant rate hydrogen and electron flow via chain enzymes: NAD/NADH, NADP/NADPH, FAD/FADH, cytochromes $\left(\mathrm{Fe}^{3+} / \mathrm{Fe}^{2+}\right)$ dynamic equilibrium is established between oxidized and reduced forms of enzymes in a cell, which is defined by redox potential (RP).

During hypoxia transport of $\mathrm{H}^{+}$and $\mathrm{e}^{-}$ceases and accumulation of reduced intermediates is accompanied by a RP decrease. According to potentiometric measurements in dog kidney and heart [34] after blood vessels ligation, RP dropped within $0.5-1$ min. In dynamics, there are 3 periods of energetic changes:

i) Rapid loss of RP after 15-20 min ischaemia, glycolysis activation, accumulation of Krebs cycle products.

ii) An intermediate period after 20-30 min ischaemia which is characterized by slow RP changes and futile $\mathrm{H}^{+}$and $\mathrm{e}^{-}$transport.

iii) The final stage is associated with glycolysis attenuation and glycogen depletion moving towards irreversible changes in the whole redox cycle.

Hypothermia substantially increases resistance of organs and tissues to lack of $\mathrm{O}_{2}$ and reduces thermal excitation of molecules, hence strengthening Van der Waals interaction and hydrogen bonds. According to the Arrhenius equation temperature change from normothermia to close to $0{ }^{\circ} \mathrm{C}$ decreases metabolic rate about 5 times whilst $\mathrm{O}_{2}$ diffusion is depressed 4 times only, indicating that $\mathrm{O}_{2}$ starvation in cooled organs results rather from enzyme inhibition than oxygen dif- fusion, imbalance in ion redistribution is linked with water homeostasis and oedema. The breakdown of ATP results in accumulation of purines and nucleoside bases - inosine, xanthine hypohantine (as discussed above). Increased levels of intracellular phosphate ions promote further $\mathrm{Ca}^{2+}$ and $\mathrm{Na}^{+}$ion intake which further exacerbate osmotic state of cell, adversely affecting mitochondrial structure and lysosomal integrity. The goal of preservation solutions is to try and intervene in as many of these changes as possible.

\section{Collins Solution}

The general strategy of cold preservation solutions implies protection of intracellular spaces upon the onset of ischaemic damage. The development of the artificial preservation solution introduced by G.M. Collins, was based on a combination of high potassium ion content and osmotic barrier supported by glucose [35]. Successful preservation of kidney, heart, liver and lung using Collins solution was associated with shortening of storage time. This may be attributed to relatively low protective properties of glucose and slow penetration of the sugar as well as acidosis aggravation due to glucose conversion to lactate. Modification of original Collins solution by substitution of glucose for mannitol [36] or sucrose provided excellent protection during prolonged cold ischaemia; this argued for the substitution of sucrose, mannitol, or other similar protective impermeant agents. Omitting of magnesium phosphate because of concern about magnesium crystal precipitations, which had been reported when using the original solution [37], increased chemical stability of Euro-Collins. Collins solution or its more recent variant - Euro-Collins - was widely distributed for organ preservation until the late 1980s.

\section{Citrate Solutions (Marshall/Ross)}

Marshall citrate solution and its modifications were developed as an alternative to Collins solution. The electrolytic composition was characterized by high potassium, sodium and magnesium content. Citrate was added to replace phosphate and as buffer agent to maintain intracellular $\mathrm{pH}$. To provide appropriate buffer capacity, citrate can be replaced with hydroxyethylpiperazine-ethane sulphonic acid (HEPES) [38]. The mechanism of action of citrate is presumably linked with chelation of magnesium - the semi-permeable molecule formed between cation and conjugate acid may support membrane integrity [39], however, the mechanism of action is still uncertain. The calcium binding capacity of citrate helps to prevent detrimental cation accumulation in the cytosol. Replacement of glucose for mannitol provided better osmotic properties and low viscosity. The short period of safe preservation for the kidney of 24-30 h [40] is sufficient to share organs internationally; however, shortenings of safe cold storage for liver limited its application. 


\section{University of Wisconsin Solution}

The University of Wisconsin (UW) solution has been the accepted as the gold standard for preservation of liver grafts since 1989 and is usually referred to as an intracellular-type solution. Study of $\mathrm{Na}^{+}$and $\mathrm{K}^{+}$redistribution using microdialysis technique suggests that $\mathrm{Na}^{+} / \mathrm{K}^{+}$diffusion into interstitial spaces may not follow the stoichiometric rule of $3: 2 \mathrm{Na}^{+} / \mathrm{K}^{+}$ exchange, and hence interstitial $\mathrm{Na}^{+} / \mathrm{K}^{+}$ratios do not fully equilibrate with the intracellular medium following cold storage [41]. This hypothesis agrees well with successful clinical and experimental applications of high-sodium UW solution which meets requirements for heart transplantation.

The advantages of UW solution compared to Marshall solution and Euro-Collins have been proven in large number of experimental and clinical studies [42-44]. An introduction of metabolically inert substrates such as lactobionate and raffinose made UW solution universal for multiple organ preservation. The combination of two osmotically active components enables successful transplantation outcome and better physiological function and less histological damage of kidney than Euro-Collins [45]. In case of marginal donor organs, UW solution-preserved organs showed a lower rate of primary non-function and rejection rate during the first 12 months after transplantation [46].

The preservation strategy of UW solution can be described in major points as follows: prevention of oedema (raffinose, lactobionate), supplementation with precursor of ATP (adenosine), and antioxidant defense (allopurinol, reduced glutathione). Numerous studies have discussed possible protective roles of individual compounds, with a view to simplify medium composition without loss of effectiveness. Interpretation of the relative significance of the substances is often ambiguous due to organ specificity and their possible synergetic action [47]. A comparative study of UW with adenosine-free solutions demonstrates that UW solution did not show significantly higher levels of ATP and only in living donor transplants where the cold ischaemic time is short may there be some advantage to the addition of adenosine [48]. Both reduced glutathione [49] and allopurinol [50] in UW solution demonstrated substantial protective effects against reactive oxygen species upon ischaemia and re-perfusion. HES in the solution has been intended to improve oncotic support of preservation medium. However, blood in combination with UW solution at $4{ }^{\circ} \mathrm{C}$ makes a by 1.3 times higher viscous mixture than blood at $37^{\circ} \mathrm{C}$, which complicates tissue wash-out and saturation with preservation solution. Omission of HES in simplified versions of UW solution is not followed by adverse effects during simple cold storage.

In the early 1990s transplantation centres in the USA and Europe demonstrated less degree of cellular oedema and fast recovery of kidney function with UW solution. Considerable improvement has been achieved in liver transplantation, providing better integrity of sinusoidal endothelial cells which are highly susceptible to cold ischaemia, Kuppfer cell activation, and apoptosis, which extended the limit of safe preservation of liver up to $24 \mathrm{~h}$ [51]. UW solution has shown its superiority over early solutions in pancreas, heart, kidney and lung preservation, and became common for harvesting of different organs allowing for a broadened geographic area of organ sharing.

\section{Bretschneider's (Custodiol) Solution}

Histidine-tryptophane-ketoglutarate (HTK) solution was introduced by H.J. Bretschneider. Initially developed for cardiac surgery, it was shown to be effective in both liver and kidney preservation, and appeared to compete with UW solution in the experimental and clinical preservation of the kidney [52] and liver [53]. Major components are the strong buffer (histidine), osmotic barrier(mannitol), and low-permeable amino acids (tryptophan and alpha-ketoglutaric acid) which help to stabilise cell membranes and may be substrates for anaerobic metabolism. Electrolyte composition is characterized by low concentrations of $\mathrm{Na}^{+}, \mathrm{K}^{+}$, and $\mathrm{Mg}^{2+}$ which therefore allow a safe direct release into recipient's blood circulation. In addition, the low viscosity of HTK solution provides more effective flushing and rapid cooling of organs.

The efficacy of the low $\mathrm{Na}^{+}$and $\mathrm{Ca}^{2+}$ content of HTK solution has been demonstrated in a number of studies. The advantages of the solution are based on basic properties of the combination histidine buffer to compensate cellular acidosis and to prolong an anaerobic glycolysis.

A randomised study performed by Eurotransplant confirms that HTK and UW solutionx are comparable in the clinical preservation of liver, with exception of biliary complications [54]. However, more recent analysis of the UNOS database (years 2004-2008) indicate that, if there are additional graft factors such as donation after cardiac death, HTK preservation was associated with an increased risk of graft loss with cold ischaemia time over $8 \mathrm{~h}$ [55]. Despite single critical papers, Bretschneider's solution showed results similar to those obtained with UW solution with respect to renal or hepatic function when organs are preserved within the safe preservation periods As lower preservation costs per donor case are also obtained [56], HTK solution has become increasingly popular over last 20 years, especially in clinical services in developing countries.

\section{Celsior Solution}

Celsior solution is a recently developed extracellular-type solution (high $\mathrm{Na}^{+}$) that adopted many of the principles of UW solution (lactobionate and mannitol) and the strong buffer from Bretschneider's HTK solution (histidine). In contrast to UW solution, reduced glutathione is the only antioxidant 
available in this solution. Initially designed for heart transplantation, it is now being clinically tested in other abdominal organs. The solution provides excellent lung preservation [57] and proved to be effective in experiments with pancreas preservation [58] and kidney storage [59]. Better tissue cooling [60], excellent properties in prevention of cell swelling, free radical scavenging, and energy depletion may encourage the future experimental and clinical studies with Celsior solution.

\section{Kyoto University Solution}

Recently a research group in Kyoto University, Japan, developed a new solution for cold preservation of organs. The authors emphasise the importance of saccharides and electrolytes during hypothermia and developed their original Kyoto trehalose-containing solution. Trehalose is a natural alphalinked disaccharide formed by an $\alpha, \alpha-1,1$-glucoside bond between two $\alpha$-glucose units. Osmotic pressure in medium is provided by $120 \mathrm{mmol} / \mathrm{l}$ trehalose and enforced by $100 \mathrm{mmo} / \mathrm{l}$ gluconate, and $30 \mathrm{~g} / \mathrm{l} \mathrm{HES}$ which together may offer sufficient protection against cellular swelling. There are two versions of the medium - extracellular ET-K $\left(\mathrm{Na}^{+} 100 \mathrm{mmol} / \mathrm{l} ; \mathrm{K}^{+} 44\right.$ $\mathrm{mmol} / \mathrm{l})$ and intracellular IT-K $\left(\mathrm{Na}^{+} 20 \mathrm{mmol} / \mathrm{l} ; \mathrm{K}^{+} 130\right.$ $\mathrm{mmol} / \mathrm{l}$ ) - that have been initially introduced in experiments with lung preservation [61]. ET-K provided less damage of vascular endothelial cells after 20-hour cold storage, with higher alveolar $\mathrm{O}_{2}$ partial pressures on re-perfusion than in the Euro-Collins study group, challenging the concept that high potassium environments may cause pulmonary artery constriction and adversely affect the tissue functional state. Interestingly, ET-K has a potential to be improved by supplementation with N-acetylcysteine (ROS scavenger), dibutyryl cAMP (second messenger) and nitroglycerin (NO donor). Modified 'New ET-K' provided a two-fold higher survival rate after $30 \mathrm{~h}$ of canine lung preservation as compared to UW solution. The efficacy of ET-K supplemented with db-cAMP was investigated for liver cold storage (24 h), showing better sinusoidal lining integrity than in the UW group [62]. ET-K was superior to Celsior solution in pancreas cold storage and islet isolation [63] and so appeared to be a novel candidate for the procurement and preservation of multiple organs

\section{IGL-1 Solution}

IGL-1 solution was developed in the Institute Georges Lopez, France, also for multi-organ preservation in the beginning of 21 th century. The composition of the medium is identical to simplified UW solution an characterised by a 'extracellular' type, high-sodium/low-potassium ratio. Substitution of HES in IGL-1 for another colloid $-0.03 \mathrm{mmol} / \mathrm{l}$ polyethylene glycol with a molecular weight of $35 \mathrm{kDa}$ (PEG-35) - has been shown to provide adequate endothelial cell protection and antioxidant defense. Pre-clinical results with IGL-1 in renal transplantation showed significant reduction of expression of major histocompatibility complex (MHC) type II, reduction of markers of apoptosis [64], and superior creatinine clearances during the first 15 postoperative days for kidneys preserved when compared with UW solution [65]. Pilot studies of liver preservation demonstrate successful orthotropic liver transplantation. Improved survival is supported by histological data suggesting smaller areas of necrosis and ameliorated microcirculation of hepatic tissue after re-perfusion [66]. PEG is an interesting substitute colloid for organ preservation. Application of PEG with relatively low molecular masses might be beneficial in transplantation applications. Addition of $1 \%$ PEG-8000 to sucrose-based balanced salt solution (SBS) improved biochemical indices during cold storage of rodent livers [67]. Protective action of PEG 8000 is supported by results of rabbit renal transplantation using SBS. Despite a similar survival after preservation with either SBS or hypertonic citrate solution, severe histological impairment was observed in SBS alone, which was significantly reduced by PEG addition [68]. Protective actions of PEG are not yet fully elucidated. However, PEGs are thought to stabilise the lipid monolayer in cell membranes, and the polymer has different effects on monolayers under low (fluid membrane) or high (condensed lipid bilayer) surface pressure that characterise compression of glycerophospholipids in the monolayer. Under condition of low surface pressure, PEGs stabilise membrane [69]. Part of this effect is associated with the dehydrating ability of PEGs to reduce the lipid molecular motion, which may cause denser packing of the lipids and a decrease in the membrane fluidity [70]. On the contrary, PEGs have been shown to lower monolayer surface pressures and to increase area per lipid at the 'collapse point' where glycerophospholipid have the dense packaging. Hypothermia imposes lipid phase transitions in membranes, which influences the conformation of lipid packing, and the lowering effect of PEG may be evident in membrane regions with saturated phospholipids and in less degree on unsaturated acyl chains in membrane monolayer. Along with temperature, the ion strength and $\mathrm{pH}$ of the environment are extremely important parameters which have direct effects on PEG's binding properties. Additional studies are needed in the future to get more specific data about the polymermembrane interactions and how this may stabilise membranes in beneficial ways.

\section{Clinical Preservation of Individual Organs at the Present Time}

At present, hypothermic storage is the most common method for whole organs using one of the two methods described above-SCSHMP. In general, preservation times of $24 \mathrm{~h}$ or less are used, depending on the organ in question. 


\section{Kidney}

The kidney is the most widely transplanted organ with the longest history of preservation research. Simple SCS can reliably provide good early function in the majority of grafts where storage times over $36 \mathrm{~h}$ have not been required within modern integrated transplant networks.

\section{Renal Preservation by SCS}

Historically, the various Collins solutions [9, 35] quickly found acceptance for renal SCS [71]. Subsequently, from the early 1990s the UW solutions or variants of this became the gold standard. However, comparable results are achievable by a variety of other solutions when preservation times do not exceed $24 \mathrm{~h}$, and under these conditions solutions such as Marshall's Hypertonic Citrate (also known as Soltran) or Celsior solution shows similar efficacy [17]. For shorter anticipated preservation periods and for living-donor transplantation, several other solutions including HTK solution may be applied [72].

The established practice for cadaver kidneys which developed early in clinical renal preservation [73] is to submerge the kidney in iced saline slush and complete the flush via the renal arteries until the effluent is clear of blood. Each kidney is then surrounded with the perfusing solution, placed in sterile containers (usually double sterile plastic bags), and stored in ice in an insulated container.

\section{Renal Preservation by $H M P$}

Continuous HMP is an alternative method for renal preservation which was promoted in some of the first clinical studies [10]. However, the increased complexity associated with early equipment led to a decline in popularity for this method, with only a few centres world-wide practicing the method by the 1990s [74, 75]. The advantage of HMP over SCS was not clearly demonstrated in some trials [76]. Revolutionary new designs for kidney perfusion machines and a shift towards marginal donors led to a re-evaluation of HMP. A prospective multicentre trial has demonstrated a clear outcome benefit for both delayed graft function and graft survival at 1 year [28]. The perfusate used was a formulation of UW solution, where lactobionate was replaced by gluconate as suggested in early organ perfusion studies by Belzer's group. Studies on cost-effectiveness of HMP over SCS will continue over the coming years, but they are beginning to identify the overall value of HMP [77].

\section{Liver}

The current status for clinical liver preservation is similar to that of the kidney, with SCS being the most common method.

\section{Liver Preservation by SCS}

Early clinical liver transplant programmes depended on the use of the first generation of flush solutions (Collins or Mar- shall's Citrate) [78, 79]. Preservation times were under $10 \mathrm{~h}$. The introduction of UW solution allowed good preservation to be extended to around $15 \mathrm{~h}$ [51]. A common practice for the liver in multi-organ donation is to flush the hepatic vasculature in situ via both aorta and portal vein initially with a low viscosity preservation solution such as Marshall's Citrate, and then to replace this with UW solution as the 'gold standard' during organ excision and packaging for transport.

Since there are no external liver support systems currently available in the clinic, good immediate graft function for liver grafts is essential. Nevertheless, about $10 \%$ of liver grafts show initially poor graft function, and about $5 \%$ have primary nonfunction. Whilst standard UW formulation is most widely used, some modifications, especially in the balance of sodium and potassium ions, have been proposed in small studies [80] with a move to low-sodium, high-potassium balance. However, there have been no prospective clinical trials to fully evaluate this. Celsior solution (another variant of the lactobionate/raffinose mixture) has also been used in some clinical liver studies [81]. Also, over the past decade, HTK solution has been used in some liver centres. Available evidence suggests that the outcomes may be similar when using either UW or HTK solution [56], but information from large trials is not yet available.

\section{Liver Preservation by HMP}

In a similar fashion as for the kidney, the metabolic benefits of HMP for the liver have been expounded since early studies in canine [82] and porcine [83] livers showed good graft preservation. Resuscitation of energy metabolism during oxygenated HMP has been shown in large animal studies [84]. However, the translation to the clinic for liver HMP has been even more challenging because the liver receives a dual blood supply via both the portal vein and hepatic artery. It was not until very recently that the first application of clinical liver HMP has been reported [85]. In 20 cases, liver HMP was performed for between 3-7 h with a new variant (Vasosol) of Belzer's original gluconate raffinose mix. There were some indications of improved early graft function when compared to livers stored by SCS, but much larger trials are now required and will be a focus of attention over the next 5 years.

\section{Heart}

Cold storage of the heart is one of the most challenging fields for organ preservation because of the high sensitivity of cardiac muscle to hypoxic injury and the serious perioperative consequences of inadequate preservation, leading to poor early graft function with associated high morbidities and mortalities. Careful selection of donor hearts is mandated.

\section{Cardiac Preservation by SCS}

There are two steps in cardiac SCS. First cardiac activity is stopped in a controlled fashion by flushing the vascular bed of 
the organ with chilled cardiaplegic solution to cool and wash out the blood [86]. Solutions such as St Thomas' cardiaplegic solution are used in the majority of centres, and hyperkalaemia is one facet of the cardiaplegic requirement, which overlaps with the concept of high potassium flush solutions in other organs. Then hearts are generally also topically cooled with chilled sterile saline before packing and storage in ice. This gives satisfactory preservation in the range of 4-6 h. Some centres prefer a blood-based cardiaplegia where donor blood is mixed with the crystalloid cardiaplegic solution such as Buckberg solution [87]. Many animal studies have been carried out on modifications of the standard method [17]. However, the application of other preservation solutions such as UW solution has not been widespread, mainly because of concerns about the effects of some components (such as lactobionate) which may alter cardiac muscle physiology in a way which compromises the early resumption of good contractility. Some centres have moved to using UW solution in small trials [88], but larger multi-centre studies are needed to confirm benefits from using more complex solutions.

\section{Cardiac Preservation by HMP}

Given the sensitivity of the heart to hypoxia, the prospect of using metabolic support through perfusion has obvious advantages. Early studies by Cooper et al. [89] suggested that baboon hearts were capable of life-sustaining function after prolonged HMP. There were limited trials of HMP in the clinic [90]. However, translation of these and other animal studies [91] to the clinic have been slow, in part due to the lack of reliable transportable equipment, but there continues to be interest in the technology [92]. The nature of the perfusing medium is also a matter of debate, with concerns raised about oxidative stress when using blood-based solutions [93], whilst intermittent perfusion has been advocated to reduce oedema formation [94]. Early clinical trials are currently ongoing using cardiac machine perfusion at normal physiological temperatures (the Transmedic technology) where the oxygencarrying capacity of whole blood is required, and results from these and other studies will shape cardiac organ donation for the next decade.

\section{Lung}

The lung is another organ which has historically presented a significant challenge for organ preservation due to high sensitivity to hypoxic injury.

\section{Lung Preservation by SCS}

The mainstay of clinical lung preservation has been simple hypothermic immersion of inflated lungs following flush of the pulmonary artery with chilled preservation solution. Low potassium solutions such as the Wallwork solution have been favoured [95]. Low potassium dextran solutions, such as Per- fadex, sometimes mixed with donor blood, have been used by some centres, whilst the value of the blood component has been questioned [96]. Other low potassium crystalloid solutions such Celsior solution have more recently been introduced for lung preservation [97]. The importance of lung donor optimisation in the overall ability to achieve good outcomes has recently been highlighted [98]. The routine application of lung inflation during preservation renders the lungs capable of some aerobic metabolic activity and has led to increased interest in including NHBD donor lungs for clinical preservation [99].

When considering lung preservation, it should be mentioned that there are occasions where lungs and heart are cold preserved en bloc. These have often employed cold carioplogic arrest of the heart followed by pulmonary flush of a second preservation solution (such as Euro-Collins solution) for the lungs [100].

\section{Lung Preservation by HMP}

Continuous perfusion preservation was investigated early in the history of lung transplantation, often at temperatures close to the physiological norm, using blood-based perfusates [101]. However, significant problems with organ oedema and IRI were encountered, leading to high early graft dysfunction. True continuous perfusion was recognised as complex because of the associated question about whether to maintain mechanical ventilation alongside vascular perfusion. A modification of vascular perfusion (hypothermic oxygen persufflation via the coronary artery) has been successfully adapted for lung preservation in porcine lung [102]. There are also proposals to use warm continuous perfusion for assessment of lung function after SCS [103]. However, these methods have yet to reach widespread application in the clinic.

\section{Pancreas}

There has been continued growth of whole pancreas transplantation over the past 5 years, requiring reliable preservation protocols.

\section{Pancreas Preservation by SCS}

During abdominal multi-organ harvesting, the vascular bed of the pancreas is flushed via the aortic route. UW solution was in fact introduced to improve pancreas preservation [1] and continues to be the chosen preservation solution in many centres. Other solutions such as HTK and Celsior solution have also been used in the clinic [104]. A recent randomised clinical trial comparing UW and Celsior solution found no differences in graft outcome [105]. Some centres in France are starting to use IGL-1 solution for the pancreas, but results have not yet been widely reported.

Pancreas preservation also encompasses storage for isolation of islets of Langerhans. The same SCS approaches are 
applied, but there has been additional interest in using perfluorocarbons in combination with UW solution to improve oxygen supply to the organ [106]. Because of the different densities of the solutions, the graft locates at the interface of the two solutions. However the value of this manoeuvre for improving subsequent islet yield has been questioned [107].

\section{Pancreas Preservation by HMP}

Preservation by HMP was investigated early in the history of pancreas transplantation, with good reported outcomes [108]. Concerns about oedema and vascular injury, coupled with logistical difficulties, led to a decline in interest in the technique. The arrival of the new generation of perfusion machines has led to a resurgence of interest in pancreatic HMP, particularly in islet isolation [109]. The effect of HMP to induce mild tissue swelling has been proposed as one factor in good islet yields [13]. The perfusate used was Belzer's machine preservation solution. Pancreas HMP for whole organ transplantation has yet to be re-evaluated with the new technologies.

\section{Small Bowel}

Small bowel preservation is one of the less frequent applications of clinical organ preservation, but nevertheless is a focus of considerable research. As with other intestinal organs, intravascular flushing via aortic cannulation using acellular preservation solutions has been the main approach [110]. The luminal surface of the intestine is sensitive to cold hypoxic injury such that methods to flush both the bowel vascular bed and the lumen with UW solution improved preservation in experimental studies [111]. IRI following bowel cold preservation can result in loss of intestinal barrier function and significant morbidities from bacterial infection post-transplant [112]. More recently UW vascular flush with UW solution and synchronous luminal flush with a nutrient-rich solution containing many amino acids has shown good outcomes in large animal small bowel preservation [113]. This approach also provided control of preservation-related oxidative stress and may lead to a new approach for small bowel preservation over the next few years.

\section{Composite Tissue Allografts}

The global interest in clinical transplantation of composite tissue allograft has spotlighted the need for adequate preservation. Once again, vascular perfusion is recommended to clear the microcirculation of residual blood. UW solution has been used as the main preservation solution [114]. The clinical applications will drive further research into cold preservation of tissues which have so far been only rarely studied [115].

\section{Summary of Approaches to Individual Organ Preservation}

The techniques for SCS, as outlined above, have remained largely unchanged over the past 20 years [17, 25]. In contrast over the past 5 years, there has been a revival of interest in HMP and other perfusion-related modalities [116], which is likely to continue into the next decade.

\section{Current Practices in Organ Preservation in Different Locations}

There are many different aspects to delivery of organ preservation services in different countries, reflecting different organisational, social and economic circumstances. The following brief descriptions represent such a spread of activity in the countries encompassing the UNESCO Chair authors of this review.

\section{Argentina}

In the last 5 years, 1,001 organ transplants were performed in Argentina. These include 635 kidney, 214 liver, 50 heart, 49 kidneys and pancreas, 36 lung, 5 combined kidney and liver, 4 combined heart and kidney, 3 intestinal, 2 combined liver and intestinal, 2 combined heart and lung, and 1 combined heart and liver and pancreatic transplant. Moreover, 711 corneas were transplanted.

All these activities have been coordinated by the Instituto Nacional Central Unico Coordinador de Ablacion e Implante (INCUCAI), which was founded. The INCUCAI is the agency that promotes, establishes the regulations, coordinates, and monitors the activities of donation and transplantation of organs, tissues, and cells in Argentina. Acts in the Argentina provinces alongside 24 jurisdictional bodies of ablation and implant in people provide a transparent and equitable access to transplantation [117].

\section{$U K$}

There has been recent governmental support for organ donation in the UK, and the numbers of organ donation events increased to 2,100 in 2009/2010, which included about 1,000 live donor transplants. In order to sustain and improve these organ donations, in 2010, the major organ procurement centres (now about 10 in numbers) in the UK joined together under the National Organ Retrieval Service (NORS) within NHS Blood and Transplant. The concept is to provide a high quality organ procurement and preservation service capable of continuous rapid response across the whole country. The teams are stand-alone and include lead and assistant surgical staff, an organ preservation technician, and an experienced theatre assistant. The service is supported by independent donor trans- 
plant co-ordinators involved in consent and counselling within the organ donation scenario. The move to NORS may lead to a unified procedural approach to organ preservation in the future, but this is currently under consultation [118].

\section{Ukraine}

Before an acceptance in Ukraine law 'About Transplantation of Human Organs and Other Anatomic Materials' in 1999, the so-called routine method of organ retrieval suitable for transplantation had been accepted in the former USSR. At the time of passing an act in Ukraine, 5 transplantation centres conducted 100-150 operations annually using cadaver organs. The law of transplantation is based on presumption of disagreement - a procedure, which requires donor written consent for organ donation in case of his/her death or written consent of his relatives after death. Society appeared not to be ready to accept the rules of the informed consent, especially when permission papers must be signed beforehand. As a result, the transplant activity in the country diminished sharply and remains extremely rare at present.

An annual necessity for 4,000 kidney transplantations is estimated in the Ukraine, and 1,500 and 1,000 persons are on a waiting list for liver and for heart transplants, respectively. Only 125 transplantations were performed in Ukraine in 2009. From that 112 are kidney and 13 liver transplantations. In most cases, transplantations were done using organs from living donors.

The general number of cadaver transplants in Ukraine in 2009 was reported to be 24 , and all of them were kidneys. This current tragic state of transplantation in Ukraine affects not only transplantation of whole organs but also cellular transplantation that are legally set equal to whole organs.

Obviously, transplantation of organs retrieved from a living donor does not require long-term organ storage, and, accordingly, application of complex storage solutions and perfusion to sustain their function remains less important. From this position, work on such approaches to increase the terms of safe hypothermic storage are of mainly academic interest.

With a view to increasing the of numbers of transplantations of cadaver material, attempts has been made to change the public perception of organ donation, Moreover, the principle of presumption of disagreement in the national Ukraine law of transplantation should be replaced by the principle of presumption of agreement, and instructional work in the Ukrainian population regarding donor-ship is currently underway. In spite of this, the transplantation activity in the Ukraine remains low. The poor economic situation does not allow assigning significant funds to carry on the relevant public educational work and to develop transplantation services on the whole. For the same reason, the current task of researchers in experimental medicine is the development of cost-effective strategies for organ preservation.

\section{New Developments to Improve Organ Preservation}

\section{Isolated Perfusion at Elevated Temperatures}

The concept of near to full physiological support of organs outside the body has been around for many decades, but has only recently moved forward to near-clinical application. One major issue has always been to supply sufficient oxygen and the full range of nutrients to support metabolism, and, equally importantly, to avoid metabolic stress in an organ re-warmed close to normothermia where substrates or oxygen may be individually delivered at sub-optimal concentrations. Some groups have developed acellular solutions capable of organ support at slightly reduced temperatures $\left(32^{\circ} \mathrm{C}\right)$ [119], and these have been applied to human kidneys in small studies [120]. Other groups have developed blood-based ex vivo circuits which have been shown to support good function in porcine liver models [121]. These new approaches will help to optimise organ perfusion technology and our understanding of the isolated perfusion process. They may indeed represent exciting new possibilities for the future of organ preservation [122].

\section{Ischaeamic Pre-Conditioning and Trophic Factors in Organ Preservation}

The molecular signalling cascades which result from ischaemic pre-conditioning (prior exposure of organs to short periods of hypoxia and re-perfuion, which elicit natural stress responses and prove cytoprotective against later ichaemic insult) have been widely investigated over the past decade [123]. The induced responses depend on numerous pathways including the induction of nitric oxide synthases, haeme oxygenase, anti-apoptotic pathways and adenosine-related cytoprotection [124]. The protection can be achieved by remote pre-conditioning where distant parts of the body (e.g. limb) can be subject to pre-conditioning and protect the liver [125]. The hope has been that these pathways could be recruited to improve the overall outcome in organ preservation, but so far the evidence has been equivocal $[125,126]$. It seems that we need to have much greater understanding of how circumstances like brain death in organ procurement affect these evolutionary stress response, and how hypothermia may impact on the signal pathways before this can become a useful clinical therapy.

\section{Gene Therapy}

Gene transfer is a promising therapeutic option for solid organ transplantation and in the prevention of IRI in transplant recipients. The transplant setting provides a unique advantage in that a graft can be efficiently transduced before transplantation by donor pre-treatment or gene delivery dur- 
ing cold preservation [127] and in protocols for ex vivo modification. In the recipient, the therapeutic gene will be expressed after transplantation [128].

Two different techniques are generally utilized to introduce genetic material into cells or tissues: gene transfer using recombinant viruses or techniques based on non-viral gene transfer (e.g. electroporation, lipid- or liposomally mediated gene transfer). In contrast to viral vectors, these gene transfer techniques generally do not induce an immune response in the recipient although their application is limited due to their low efficiency in vivo $[129,130]$.

To the best of our knowledge, there is no clinical study using gene therapy to reduce IRI in transplant patients, although many pre-clinical models show quite promising and exciting results.

Examples of gene transfer in the pre-clinical stage:

- gene transfer of anti-oxidative molecules

- gene transfer of anti-apoptotic molecules

- gene transfer of cytoprotective (heat shock) proteins

- gene transfer of HO-1-inducing molecules

- gene transfer of cytokines and cytokine antagonist

- blockade of T cell co-stimulation.

\section{Cryopreservation}

True long-term storage of any organ would require cooling to ultra-low temperatures (below $-100{ }^{\circ} \mathrm{C}$ ) in the process of cryopreservation. Whilst this has been a long-standing dream within the field of organ transplantation, there are very significant challenges for organ function which take place when large, three-dimensional structures are cooled below freezing point and ice inevitably starts to form [131]. Even if special protective chemicals (known as cryoprotectants) are introduced and careful control of cooling and warming are imposed, injury occurs. A good understanding of many of the challenges in organ cryopreservation has been obtained over the past 3 decades [132], and some progress has recently been possible. Using directional solidification during cooling, a process to control distribution and format of ice crystals, it has been possible to cryopreserve whole ovaries in sheep, with successful long-term function [133]. The same technology has been applied to murine abdominal organs in preliminary studies [134]. Whole ovaries are smaller than most solid organs, but they do represent a complex mix of cells requiring support from an intact vascular system, which has been one of the 'Achilles heels' of organ cryopreservation.

Another route to ameliorating the organ injury from ice formation is to completely suppress ice nucleation by a process called vitrification $[131,135]$. The technology has proved very successful in cryobanking small cell clusters such as embryos in reproductive medicine [136]. However, this requires extremely high concentrations of cryprotectant, in the region of $60 \%$ weight/volume, which introduces significant problems of toxicity and tissue distribution. Nevertheless, progress has been made at the level of complex tissues such as intact blood vessels [137]. It is expected that further progress in organ cryopreservation will be made over the next decade, but the technology currently is far away from being implemented into clinical organ transplant services.

\section{Pharmacological Manoeuvres}

To either prevent organ damage due to ischaemia or cell activation or infiltration of mononuclear cells upon re-perfusion, some pharmacological manoeuvres can be performed in the donor or allgraft. The observations that bioactive gases such as nitric oxide (NO), carbon monoxide ( $\mathrm{CO}$ ), and hydrogen sulphide $\left(\mathrm{H}_{2} \mathrm{~S}\right)$ promote the survival and/or function of organ, tissue, and individual cell transplants has become another strategy to improve the success of organ transplantation [138].

$\mathrm{CO}$, a by-product of haeme catalysis by haeme oxygenases (HO-1, HO-2, HO-3), has been shown to have cytoprotective and anti-inflammatory effects. Inhalative therapy, however, is applicable only after ischaemic challenge and implies the necessity of controlled ventilation. Moreover, $\mathrm{CO}$ inhalation bears the risk of adverse cardiac side-effects like dysrhythmia and decreased cardiac performance or even infarction. Using the rat liver transplantation model, it has been reported that brief recipient $\mathrm{CO}$ inhalation during the peritransplant period ameliorates liver graft damage and inhibits pro-inflammatory responses during transplant-induced cold hepatic IRI [139]. Inhalation of $\mathrm{CO}$ at a low concentration provides protection of kidney grafts against cold IRI and preserves overall improved kidney graft functioning following transplantation [140]. Accordingly, ex vivo delivery of CO into the preservation solution prior to flush out and cold storage has been tried and resulted in reduced inflammatory response and better gut barrier function upon intestinal transplantation in rats. A safer alternative is the use of CO-releasing molecules, a novel class of pharmaceutical drugs [141], which have been successfully applied in pre-clinical animal models for heart [142], kidney [143], and liver transplantation [144].

NO, normally synthesised from L-arginine by NO synthase (eNOS), shares at least one common mechanism of action with $\mathrm{CO}$, i.e. they both stimulate guanylate cyclase. Cold IRI in liver grafts from wild type donors was significantly attenuated compared to eNOS-deficient donors after liver transplantation [145].

The third potential gaseous mediator that protects against IRI is $\mathrm{H}_{2} \mathrm{~S}$, a colourless, toxic and flammable gas. Although data available thus far look promising, more work is required before $\mathrm{H}_{2} \mathrm{~S}$ can be used as a cytoprotective mediator in organ transplantation [146].

The future of medical gas therapy must focus on the establishment of safe and well-defined administration parameters, and on randomised controlled trials are necessary to determine the precise indications and guidelines for the use of medical gases in the treatment of various pathologies. 


\section{Cell Therapy}

Along with gene therapy, cell transplantation approaches are novel and forthcoming ways to improve organ condition. Cells of different origins, particularly stem cells, may be considered as immediate sources of numerous biologically active molecules for application in organ storage. A wide spectrum of growth factors and cytokines is worth to be considered, independent from the cell source: single growth factors or cytokines, artificial mixtures of selected agents or 'physiological cocktails' from cell and tissue extracts are all of interest. Also, this field of investigation can be divided into two main categories: donor pre-treatment and supplementation of the storage solution with the test compounds. The first option is limited by ethical reasons because it may be considered as a treatment without benefit to the donor; however, in future, it may find applications in situations such as liver partial transplantation from living donors. The problems associated with the latter option are the slowing-down of substance penetration or uptake in the tissues by the low temperatures and the difficulty to control this process.

Anti-inflammatory cytokines such as IL-10 or IL-13 have been used for donor pre-treatment with single substances or for gene transfer. This approach led to improvement of liver state after cold exposure by means of modulation of immunocompetent cells and induction of stress proteins like HO-1, anti-apoptotic Bcl-2/Bcl-x(L), etc. [147-149]. The effects of donor pre-treatment with single compounds are more often studied in models of liver warm ischaemia, but these are outside the limits of this review.

For some years, he groups of Murphy and McAnulty have studied how the supplementation of preservation solution (UW solution) with mixture of some growth factors (named 'trophic factors') affects large animal liver and kidney preservation during cold storage and transplantation. This approach resulted in an increase of animal survival rate after transplantation, and in the case of kidneys, this fact was observed even after 6-day organ preservation [150, 151].

These encouraging results attracted the attention of several groups (including our own), but we gave favour to the concept that a specific 'physiologic cocktail' would be capable of providing the essential effects under cold preservation conditions. The most promising source of this 'cocktail' appeared to be stem and progenitor cells, especially mesenchymal stromal cells, as physiologically recognized powerful producers of large numbers of growth factors and cytokines $[152,153]$. One more important feature of these cells is their resistance to hypoxia [154], which in theory should be supported by appropriate regulatory and growth factor mechanisms. Our studies on rats showed that pretreatment with cytosol of human foetal tissues of mesenchymalmesodermal origin led to almost total normalisation of the liver pro-oxidant/anti-oxidant balance during $24 \mathrm{~h}$ of cold hepatic storage and following warm re-perfusion [155]. Also, we ob- served short-term significant increases of liver ATP and an overcoming of inhibition of glycolysis [156] accompanied by significant modulation of redox-dependent processes (unpublished data). Recently we studied the effect of organ preservation medium supplementation with allogeneic rat cytosol of the same origin. There were marked improvements of liver mitochondrial respiratory activity (this effect was not observed in the model of donor pre-treatment) and partial depression of free radical processes which resulted in enhanced recovery of liver function after $24 \mathrm{~h}$ of cold storage in this model.

\section{Conclusion}

This review shows how much has been learned about organ preservation over the past 50 years, transforming the topic from an area of esoteric academic research to an important clinical service transplantation medicine around the world. However, beyond our successes in being able to maintain the basic physiology of organs in this ex vivo state, there remain many gaps in our knowledge about the molecular impacts of organ preservation which will need to be addressed in the future to be able to fully optimise the process. New cytoprotective strategies are constantly being developed, and these will need to be evaluated to see if they can be incorporated into organ preservation protocols. Over the next decade, it seems clear that perfusion technologies (at hypothermia and at other temperatures) will play an increasingly important role as we learn how to sustain or even repair organ function outside the body. The challenges will continue to increase as the shortage of organs for transplantation keeps up the pressure to use more marginal organ donors. Thus, the impetus to develop new research-based ideas in organ preservation remains as high as it was at the start of clinical transplantation.

\section{Acknowledgements}

The authors would like to acknowledge the importance of the UNESCO Chair in Cryobiology in the formulation off this review for providing the international contacts and stimulating collaborative research between our groups in different parts of the world. In this respect, we have been saddened to learn that during the preparation of this review, the founder member and lead Professor in the UNESCO Chair, Valentin Grischenko, Head of the Institute for Problems of Cryobiology and Cryomedicine of the Ukraine Academy of Sciences in Kharkiv, has died. Professor Grischenko was a man of great vision, believing in the value of international collaboration for the development of young scientists around the world, and the value which this will bring to scientific progress and improved healthcare in the future.

\section{Disclosure Statement}

The authors declared no conflict of interest. 


\section{References}

1 Southard J, Belzer FO: Organ preservation. Annu Rev Med 1995; 46:235-247.

2 Fuller B, Guibert E, Rodriguez J: Lessons from natural cold-induced dormancy to organ preservation in medicine and biotechnology : from the 'backwoods to the bedside'; in E Lubens, J Cerda, M Clark (eds): Dormancy and Resistance to Harsh Environments, Topics in Current Genetics. Berlin, Springer, 2010, pp253-278.

3 Brodie T: The perfusion of surviving organs. J Physiol 1903; 29:266-275.

4 Locke FS, Rosenheim O: Contributions to the physiology of the isolated heart: the consumption of dextrose by mammalian cardiac muscle. J Physiol 1907;36:205-220.

$\checkmark 5$ Carrel A, Lindbergh CA: The culture of whole organs. Science 1935; 81:621-623.

6 Bickford RG, Winton FR: The influence of temperature on the isolated kidney of the dog. J Physiol 1937;89:198-219.

7 Schloerb PR, Waldorf R, Welsh JS: The protective effect of kidney hypothermia on total renal ischemia. Surg Gynecol Obstet 1959;109:561-565.

8 Calne RY, Pegg DE, Pryse-Davies J, Brown FL: Renal preservation by ice-cooling: an experimental study relating to kidney transplantation from cadavers. Br Med J 1963;2:651-655.

9 Collins GM, Bravo-Shugarman M, Terasaki PI: Kidney preservation for transportation. Initial perfusion and 30 hours' ice storage. Lancet 1969;2: 1219-1222.

10 Humpries AL, Russell R, Gregory J, Carter RH, Moretz WH: Hypothermic perfusion of the canine kidney for 48 hours followed by reimplantation. Am Surg 1964;30:748-752.

11 Humphries A L, Russell R, Stoddard L, Moretz WH: Successful five-day kidney preservation. Perfusion with hypothermic, diluted plasma. Invest Urol 1968;5:609-618.

12 Starzl TE, Hakala TR, Shaw BW Jr, Hardesty RL, Rosenthal TJ, Griffith BP, Iwatsuki S, Bahnson HT: A flexible procedure for multiple cadaveric organ procurement. Surg Gynecol Obstet 1984;158:223-230.

13 Taylor MJ, Baicu SC: Current state of hypothermic machine perfusion preservation of organs: the clinical perspective. Cryobiology 2010;60(suppl 1):20-35.

14 Rauen U, de Groot H: New insights into the cellular and molecular mechanisms of cold storage injury. J Investig Med 2004;52:299-309.

15 Hosgood SA, Bagul A, Nicholson ML: Minimising cold ischaemic injury in an experimental model of kidney transplantation. Eur J Clin Invest 2010; 41 233-240..

16 Feng XN, Xu X, Zheng SS: Current status and perspective of liver preservation solutions. Hepatobiliary Pancreat Dis Int 2006;5:490-494.

17 Hafez T, Fuller B: Applications: Organ preservation for transplantation; in Baust JG (ed): Advances in Biopreservation. Owego, Cell Preservation Services, 2006, vol 9, pp 197-270.

18 Elimadi A, Haddad PS: Cold preservation-warm reoxygenation increases hepatocyte steady-state $\mathrm{Ca}++$ and response to $\mathrm{Ca}++-$ mobilizing agonist. Am J Physiol Gastrointest Liver Physiol 2001;281: G809-G815.

19 Manekeller S, Schuppius A, Stegemann J, Hirner A, Minor T: Role of perfusion medium, oxygen and rheology for endoplasmic reticulum stressinduced cell death after hypothermic machine preservation of the liver. Transpl Int 2008;21:169-177.
Parks DA, Bulkley GB, Grange DN: Role of oxygen free radicals in shock, ischemia, and organ preservation. Surgery 1983;94:428-32.

21 Zhong Z, Ramshesh VK, Rehman H, Currin RT, Sridharan V, Theruvath TP, Kim I, Wright GL, Lemasters JJ: Activation of the oxygen-sensing signal cascade prevents mitochondrial injury after mouse liver ischemia-reperfusion. Am J Physiol Gastrointest Liver Physiol 2008; 295:G823-G832.

22 Semenza GL: Surviving ischemia: adaptive responses mediated by hypoxia-inducible factor 1 . J Clin Invest 2000;106:809-811.

23 Strey CW, Gestrich J, Beckhaus T, Marquez-Pinilla RM, Oppermann E, Monch C, Lambris JD, Karas M, Bechstein WO: Hypoxia and reoxygenation of primary human hepatocytes induce proteome changes of glucose metabolism, oxidative protection and peroxisomal function. Int $\mathrm{J}$ Molec Med 2010;26:577-584.

24 Lee CY, Mangino MJ: Preservation methods for kidney and liver. Organogenesis 2009;5:105-112.

25 McAnulty J: Hypothermic organ preservation by static cold storage methods: Current status and a view to the future. Cryobiology 2010;60(3 suppl): S13-S19.

26 Fuller BJ, Lee CY: Hypothermic perfusion preservation: the future of organ preservation revisited? Cryobiology 2007;54:129-145.

27 Starzl TE, Miller C, Broznick B, Makowka L: An improved technique for multiple organ harvesting. Surg Gynecol Obstet 1987;165:343-348.

28 Moers C, Smits JM, Maathuis MH, Treckmann J, van Gelder J, Napieralski BP, van Kasterop-Kutz M, van der Heide JJH, Squifflet JP, van Heurn E, Kirste GR, Rahmel A, Leuvenink HGD, Paul A, Pirenne J, Ploeg RJ: Machine perfusion or cold storage in deceased-donor kidney transplantation. N Engl J Med 2009;360:7-19.

29 Hartono C, Suthanthiran M: Transplantation: pump it up: conserving a precious resource? Nat Rev Nephrol 2009;5:433-434.

30 Van der Plaats A, 't Hart NA, Verkerke GJ, Leuvenink HGD, Ploeg RJ, Rakhorst G: Hypothermic machine preservation in liver transplantation revisited: concepts and criteria in the new millennium. Ann Biomed Eng 2004;32:623-631.

31 Dutkowski P, de Rougemont O, Clavien PA: Machine perfusion for 'marginal' liver grafts. Am J Transplant 2008;8:917-924.

32 Llarrull MS, Pizarro MD, Scandizzi AL, Bottai H, Guibert EE, Rodriguez JV: Cold preservation of isolated hepatocytes in UW solution: experimental studies on the respiratory activity at 0 degrees C. CryoLetters 2007;28:313-28

33 Lüer B, Koetting M, Efferz P, Minor T: Role of oxygen during hypothermic machine perfusion preservation of the liver. Transpl Int 2010; 23:944-950.

34 Shargorodskiı̆ BM, Rastorguev BP: Measuring and dynamic registration of the oxidizing-reducing potential of the myocardium on animals in vivo Biofizika 1965;10:652-657.

35 Collins GM, Hartley LC, Clunie GJ: Kidney preservation for transportation. Experimental analysis of optimal perfusate composition. Br J Surg 1972; 59:187-189.

36 Andrews PM, Bates SB: Improving Euro-Collins flushing solution's ability to protect kidneys from normothermic ischemia. Miner Electrolyte Metab 1985;11:309-313.

37 Heinrich G: Prevention of precipitation reactions in the production of kidney perfusion solution using the Collins method (in German). Z Urol Nephrol 1972;65:941-943.
8 Jablonski P, Howden B, Marshall V, Scott D: Evaluation of citrate flushing solution using the isolated perfused rat kidney. Transplantation 1980;30:239243.

39 Marshall MR, Ma TM, Eggleton K, Ferencz A: Regional citrate anticoagulation during simulated treatments of sustained low efficiency diafiltration. Nephrology (Carlton) 2003;8:302-310.

40 Howden B, Jablonski P, Rigol G, Birrell C, Rae D, Marshall VC, Tange J: Studies in renal preservation using a rat kidney transplant model: II. The effect of reflushing with citrate. Transplantation 1984;37:52-54.

41 Kozlova I, Khalid Y, Roomans GM: Preservation of mouse liver tissue during cold storage in experimental solutions assessed by $\mathrm{x}$-ray microanalysis. Liver Transpl 2003;9:268-278.

42 Cavallari A, Cillo U, Nardo B, Filipponi F, Gringeri E, Montalti R, Vistoli F, D'Amico F, Faenza A, Mosca F, Vitale A, D'Amico D: A multicenter pilot prospective study comparing Celsior and University of Wisconsin preserving solutions for use in liver transplantation. Liver Transpl 2003;9:814-821.

43 Mangus RS, Fridell JA, Vianna RM, Milgrom MA, Chestovich P, Chihara RK, Tector AJ: Comparison of histidine-tryptophan-ketoglutarate solution and University of Wisconsin solution in extended criteria liver donors. Liver Transpl 2008;14:365-373.

44 Testa G, Malagó M, Nadalin S, Treptow B, Paul A, Frilling A, Broelsch CE: Histidine-tryptophanketoglutarate versus University of Wisconsin solution in living donor liver transplantation: results of a prospective study. Liver Transpl 2003;9:822-826.

45 Ueda Y, Todo S, Imventarza O, Furukawa H, Oks A, Wu YM, Oguma S, Starzl TE: The UW solution for canine kidney preservation. Its specific effect on renal hemodynamics and microvasculature. Transplantation 1989;48:913-918.

46 Stevens RB, Skorupa JY, Rigley TH, Yannam GR, Nielsen KJ, Schriner ME, Skorupa AJ, Murante A, Holdaway E, Wrenshall LE: Increased primary non-function in transplanted deceased-donor kidneys flushed with histidine-tryptophan-ketoglutarate solution. Am J Transplant 2009;9:1055-1062.

47 Yu WM, Coddington D, Bitter-Suermann H: Rat liver preservation. I. The components of UW solution that is essential to its success. Transplantation 1990;49:1060-1066.

48 Corps CL, Shires M, Crellin D, Smolenski R, Potts D, Pratt J, Lodge JP: Influence on energy kinetics and histology of different preservation solutions seen during cold ischemia in the liver. Transplant Proc 2009;41:4088-4093.

49 Vreugdenhil PK, Belzer FO, Southard JH: Effect of cold storage on tissue and cellular glutathione. Cryobiology1991;28:143-149.

50 Biguzas M, Jablonski P, Howden BO, Thomas AC, Walls K, Scott DF, Marshall VC: Evaluation of UW solution in rat kidney preservation. II. The effect of pharmacological additives. Transplantation 1990;49:1051-1055.

-51 Kalayoglu M, Sollinger HW, Stratta RJ, D'Alessandro AM, Hoffmann RM, Pirsch JD, Belzer FO: Extended preservation of the liver for clinical transplantation. Lancet 1988;1:617-619.

52 den Butter G, Saunder A, Marsh DC, Belzer FO, Southard JH: Comparison of solutions for preservation of the rabbit liver as tested by isolated perfusion. Transpl Int 1995;8:466-471.

53 Rayya F, Harms J, Martin AP, Bartels M, Hauss J, Fangmann J: Comparison of histidine-tryptophanketoglutarate solution and University of Wisconsin solution in adult liver transplantation. Transplant Proc 2008;40:891-894. 
54 Groenewoud AF, Thorogood J: Current status of the Eurotransplant randomized multicenter study comparing kidney graft preservation with histidinetryptophan-ketogluterate, University of Wisconsin, and Euro-Collins solutions. The HTK Study Group. Transplant Proc 1993;25:1582-1585.

55 Stewart ZA, Cameron AM, Singer AL, Montgomery RA, Segev DL: Histidine-TryptophanKetoglutarate (HTK) is associated with reduced graft survival in deceased donor livers, especially those donated after cardiac death. Am J Transplant 2009;9:286-293.

56 Bellamy CA, Nicely B, Mattice BJ, Teaster R Comparative analysis of clinical efficacy and cost between University of Wisconsin solution and histidine-tryptophan-ketoglutarate. Prog Transplant 2008;18:166-171.

57 Wittwer T, Wahlers T, Cornelius JF, Elki S, Haverich A: Celsior solution for improvement of currently used clinical standards of lung preservation in an ex vivo rat model. Eur J Cardiothorac Surg 1999;15:667-671.

58 Hackl F, Stiegler P, Stadlbauer V, Schaffellner S Iberer F, Matzi V, Maier A, Klemen H, SmolleJüttner FM, Tscheliessnigg K: Preoxygenation of different preservation solutions for porcine pancreas preservation. Transplant Proc 2010;42:1621-1623.

-59 Nunes P, Mota A, Figueiredo A, Macário F, Rolo F, Dias V, Parada B: Efficacy of renal preservation: comparative study of Celsior and University of Wisconsin solutions. Transplant Proc 2007;39: 2478-2479.

60 Matias JE, Morais FA, Kato DM, Koziak V, Brioschi ML, Tambara EM, Agulham MÂ, Coelho JC: Prevention of normothermic hepatic ischemia during in situ liver perfusion with three different preservation solutions: experimental analysis by real time infrared radiation thermography. Rev Col Bras Cir 2010;37:211-217.

61 Chen F, Nakamura T, Wada H: Development of new organ preservation solutions in Kyoto University. Yonsei Med J 2004;45:1107-1114.

62 Zhao X, Koshiba T, Nakamura T, Tsuruyama T, Li Y, Bando T, Wada H, Tanaka K: ET-Kyoto solution plus dibutyryl cyclic adenosine monophosphate is superior to University of Wisconsin solution in rat liver preservation. Cell Transplant 2008; 1:99-109.

63 Noguchi H, Naziruddin B, Onaca N, Jackson A, Shimoda M, Ikemoto T, Fujita Y, Kobayashi N, Levy MF, Matsumoto S: Comparison of modified Celsior solution and M-Kyoto solution for pancreas preservation in human islet isolation. Cell Transplant 2010;6:751-758.

64 Badet L, Abdennebi HB, Petruzzo P, McGregor B, Espa M, Hadj-Aissa A, Ramella-Virieux S, Steghens JP, Portoghese F, Morelon E, Martin X: Evaluation of IGL-1, a new organ preservation solution: preclinical results in renal transplantation. Prog Urol 2005;15:481-488.

-65 Codas R, Petruzzo P, Morelon E, Lefrançois N, Danjou F, Berthillot C, Contu P, Espa M, Martin $\mathrm{X}$, Badet L: IGL-1 solution in kidney transplantation: first multi-center study. Clin Transplant 2009; 23:337-342.

66 Franco-Gou R, Mosbah IB, Serafin A, Abdennebi HB, Roselló-Catafau J, Peralta C: New preservation strategies for preventing liver grafts against cold ischemia reperfusion injury. J Gastroenterol Hepatol 2007;22:1564-1565.

67 Semenchenko OA, Cherkashina DV, Tkacheva EN, Lebedinsky AS, Fuller BJ, Petrenko AY: Sucrose-based preservation solution modified by PEG-8000 for cold storage of isolated rat liver. Cryobiology 2006;53:434-435.
68 Fuller BJ, Shurey C, Lane N, Petrenko A, Green C: Hypothermic renal preservation with a sucrose/ polyethylene glycol solution in a rabbit renal transplant model. Cryo Letters 2006;27:127-132.

69 Dutheil D, Underhaug Gjerde A, Petit-Paris I, Mauco G, Holmsen H: Polyethylene glycols interact with membrane glycerophospholipids: is this part of their mechanism for hypothermic graft protection? J Chem Biol 2009;2:39-49.

70 Ohno H, Sakai T, Tsuchida E, Honda K, Sasakawa S: Interaction of human erythrocyte ghosts or liposomes with polyethylene glycol detected by fluorescence polarization. Biochem Biophys Res Commun 1981;102:426-431.

71 Collins GM: Current status of renal preservation by simple flushing and hypothermic storage; in Marberger M, Dreikhorn K (eds): Renal Preservation. Baltimore, Williams and Wilkins, 1983, pp 224-243.

72 Marshall VC: Organ and tissue preservation; in Chapman JR, Deierhoi M, Wight C (eds): Organ and Tissue Donation for Transplantation. London, Edward Arnold, 1997, pp 200-214.

73 Belzer FO, Salvatierra O: Renal transplantation: organ procurement, preservation, and surgical management; in Brenner BM, Rector FC Jr (eds): The Kidney. Philadelphia, W.B. Saunders, 1976, vol 2, pp 1796-1818.

74 Henry ML, Sommer B, Ferguson R: Improved immediate function of renal allografts with Belzer perfusate. Transplantation 1988;45:73-75.

75 Polyak MM, Arrington BO, Stubenbord WT, Kapur S, Kinkhabwala M: Prostaglandin E1 influences pulsatile preservation characteristics and early graft function in expanded criteria donor kidneys. J Surg Res 1988;85:17-25.

76 Merion RM, Oh H, Port F, Toledo-Pereyra LH, Turcotte JG: Prospective controlled trial of cold storage versus machine perfusion preservation in cadaveric renal transplantation. Transplantation 1991;50:230-233.

77 Bond M, Pitt M, Akoh J, Moxham T, Hoyle M, Anderson R: The effectiveness and cost-effectiveness of methods of storing donated kidneys from deceased donors: a systematic review and economic model. Health Technol Assess 2009;13:iii-iv, xi-xiv, 1-156.

78 Benichou J, Halgrimson CG, Weil R 3rd, Koep LJ, Starzl TE: Canine and human liver preservation for 6 to $18 \mathrm{hr}$ by cold infusion. Transplantation 1977;24:407-411.

79 Badger IL, Michell ID, Buist LJ, Sherlock D, Buckels JA, McMaster P: Human hepatic preservation using Marshall's solution and University of Wisconsin solution in a controlled, prospective trial. Transplant Proc 1990;22:2183-2184.

80 Kurzawinski TR, Appleby JA, Hardy SC, Fuller B, Cheetham K, Haswell D, Davidson B, Rolles $\mathrm{K}$ : A prospective randomized clinical trial of liver preservation using high-sodium versus high-potassium lactobionate/raffinose solution.Transpl Int 1994; 7(suppl 1):S489-492.

81 Lopez-Andujar R, Deusa S, Montalvá E, San Juan F, Moya A, Pareja E, DeJuan M, Berenguer M, Prieto M, Mir J: Comparative prospective study of two liver graft preservation solutions: University of Wisconsin and Celsior. Liver Transpl 2009; 15:1709-1717.

82 Turner MD, Alican F: Successful 20-hour storage of the canine liver by continuous hypothermic perfusion. Cryobiology 1970;6:293-301.

83 Belzer FO, May R, Berry M, Lee JC: Short term preservation of porcine livers. J Surg Res 1970;10: 55-61.
84 Changani KK, Fuller BJ, Bryant DJ, Bell JD, AlaKorpela M, Taylor-Robinson SD, Moore DP, Davidson BR: Non-invasive assessment of ATP regeneration potential of the preserved donor liver. A 31P MRS study in pig liver. J Hepatol 1997;26:336-342.

85 Guarrera JV, Henry SD, Samstein B, Odeh-Ramadan R, Kinkhabwala M, Goldstein MJ, Ratner LE, Renz JF, Lee HT, Brown RS Jr, Emond JC: Hypothermic machine preservation in human liver transplantation: the first clinical series. Am J Transplant 2010;10:372-381.

86 Fleischer KJ, Baumgartner WA: Heart preservation; in Baumgartner WA (ed): Heart and Lung Transplantation. Philadelphia, W.B. Saunders, 2002, pp 135-149.

87 Luciani BG, Faggian G, Montalbano G, Casali G, Forni A, Chiominto B, Mazzucco G: Blood versus crystalloid cardiaplegia for myocardial protection of donor hearts during transplantation: a prospective randomized clinical trial. J Thoracic Cardiovasc Surg 1999;18:787-795.

88 Kur F, Beiras-Fernandez A, Meiser B, Uberfuhr P, Reichart B: Clinical heart transplantation with extended preservation time ( $>5$ hours): experience with University of Wisconsin solution. Transplant Proc 2009;41:2247-2249.

- 89 Cooper DK, Wicomb WN, Rose AG, Barnard CN Orthotopic allotransplantation and autotransplantation of the baboon heart following 24-h storage by a portable hypothermic perfusion system. Cryobiology 1983;20:385-394.

90 Wicomb WN, Cooper DK, Novitzky D, Barnard $\mathrm{CN}$ : Cardiac transplantation following storage of the donor heart by a portable hypothermic perfusion system. Ann Thorac Surg 1984;37:243-248.

91 Koike N, Takeyoshi I, Ohki S, Tsutsumi H, Matsumoto K, Morishita Y: The effect of short-term coronary perfusion using a perfusion apparatus on canine heart transplantation from non-heart-beating donors. J Heart Lung Transplant 2003;22:810-817.

92 Collins MJ, Moainie SL, Griffith BP, Poston RS: Preserving and evaluating hearts with ex vivo machine perfusion: an avenue to improve early graft performance and expand the donor pool. Eur J Cardiothorac Surg 2008;34:318-325.

93 Charniot JC, Bonnefont-Rousselot D, Albertini JP, Dever S, Vignat N, Nataf P, Pavie A, Monsuez JJ, DeLattre J, Artigou JY: Oxidative stress implication after prolonged storage donor heart with blood versus crystalloid cardioplegia and reperfusion versus static storage. J Surg Res 2010;160:308-314.

94 Nameki T, Takeyoshi I, Oshima K, Kobayashi K, Sato H, Matsumoto K, Morishita Y: A comparative study of long-term heart preservation using 12-h continuous coronary perfusion versus 1 -h coronary perfusion following 11-h simple immersion. J Surg Res 2006:135:107-112.

95 Kelly RF, Murar J, Hong Z, Nelson DP, Hong F, Varghese A, Weir EK: Low potassium dextran lung preservation solution reduces reactive oxygen species production. Ann Thorac Surg 2003;75: 1705-1710.

96 King RC, Binns OAR, Kanithanon RC, Parrino PE, Reece TB, Maliszewskyj JD, Shockey KS, Tribble CG, Kron IL: Acellular low-potassium dextran preserves pulmonary function after 48 hours of ischemia. J Heart Lung Transplant 1999;18: 320-327.

97 Xiong L, Legagneux J, Wassef M, Oubenaïssa A, Détruit $\mathrm{H}$, Mouas $\mathrm{C}$, Menasché P: Protective effects of Celsior in lung transplantation. Ann Thorac Surg 1997;64:795-800. 
98 Mascia L, Pasero D, Slutsky AS, Arguis MJ, Berardino M, Grasso S, Munari M, Boifava S, Cornara G, Della Corte F, Vivaldi N, Malacarne P, Del Gaudio P, Livigni S, Zavala E, Filippini C, Martin EL, Donadio PP, Mastromauro I, Ranier VM: Effect of a lung protective strategy for organ donors on eligibility and availability of lungs for transplantation: a randomized controlled trial. JAMA 2010;304:2620-2627.

99 Dark JH: Lung transplantation from the nonheart beating donor. Transplantation 2008;27;86: 200-201.

-100 Le Gal YM, Scott T, Prabhakaran VM, Zhang J, Pushpanathan C, Morrissey L: Heart-lung protection from ischemic injury during 8 hour hypothermic preservation. Acta Biomed Ateneo Parmense 1994;65:181-198.

101 Genco CM, Connolly RJ, Peterson MB, Bernstein EA, Ramberg K, Zhang X, Cleveland RJ, Diehl JT: Granulocyte sequestration and early failure in the autoperfused heart-lung preparation Ann Thorac Surg 1992;53:217-225.

102 Kuhn-Régnier F, Fischer JH, Jeschkeit S, Switkowski R, Bardakcioglu O, Sobottke R, de Vivie ER: Coronary oxygen persufflation combined with HTK cardioplegia prolongs the preservation time in heart transplantation. Eur J Cardiothorac Surg 2000;17:71-76.

103 Aitchison JD, Orr HE, Flecknell PA, Kirby JA, Dark JH: Functional assessment of non-heartbeating donor lungs: prediction of post-transplant function. Curr Opin Organ Transplant 2008;13: 59-66.

104 Baertschiger RM, Berney T, Morel P: Organ preservation in pancreas and islet transplantation. Curr Opin Organ Transplant 2008;13:59-66.

105 Boggi U, Vistoli F, Del Chiaro M, et al: Pancreas preservation with University of Wisconsin and Celsior solutions: a single-center, prospective, randomized pilot study. Transplantation 2004;77: 1186-1190.

-106 Kuroda Y, Kawamura T, Suzuki Y, Fujiwara H, Yamamoto K, Saitoh Y: A new, simple method for cold storage of the pancreas using perfluorochemical. Transplantation 1988;46:457-460.

107 Kin T, Mirbolooki M, Salehi P, Tsukada M, O'Gorman D, Imes S, Ryan EA, Shapiro AM, Lakey JR: Islet isolation and transplantation outcomes of pancreas preserved with University of Wisconsin solution versus two-layer method using preoxygenated perfluorocarbon. Transplantation 2006;82:1286-1290.

108 Florack G, Sutherland DE, Heil J, Squifflet JP, Najarian JS: Preservation of canine segmental pancreatic autografts: cold storage versus pulsatile machine perfusion. J Surg Res 1983;34: 493-504.

-109 Taylor MJ, Baicu S, Leman B, Greene E, Vazquez A, Brassil J: Twenty-four hour hypothermic machine perfusion preservation of porcine pancreas facilitates processing for islet isolation. Transplant Proc 2008;40:480-482.

110 Schraut WH: Current status of small-bowel transplantation. Gastroenterology 1988:94:525-538.

111 Li YS, Li JS, Li N, Jiang ZW, Zhao YZ, Li NY, Liu FN: Evaluation of various solutions for small bowel graft preservation. World J Gastroenterol 1998;4:140-143.

112 Grant D, Abu-Elmagd K, Reyes J, Tzakis A, Langnas A, Fishbein T, Goulet O, Farmer D: Intestine Transplant Registry. 2003 report of the intestine transplant registry: a new era has dawned. Ann Surg 2005;241:607-613.
113 Salehi P, Bigam DL, Ewaschuk JB, Madsen KL, Sigurdson GT, Jewell LD, Churchill TA: Alleviating intestinal ischemia-reperfusion injury in an in vivo large animal model: developing an organspecific preservation solution. Transplantation 2008;85:878-884.

114 Pomahac B, Lengele B, Ridgway EB, Matros E, Andrews BT, Cooper JS, Kutz R, Pribaz JJ: Vascular considerations in composite midfacial allotransplantation. Plast Reconstr Surg 2010;125: 517-522.

115 de With MC, van der Heijden EP, van Oosterhout MF, Kon M, Kroese AB: Contractile and morphological properties of hamster retractor muscle following $16 \mathrm{~h}$ of cold preservation. Cryobiology 2009;59:308-316.

116 Brockmann J, Reddy S, Coussios C, Pigott D, Guirriero D, Hughes D, Morovat A, Roy D, Winter L, Friend PJ: Normothermic perfusion: a new paradigm for organ preservation. Ann Surg 2009;250:1-6

117 National Health Service for Transplant organization in Argentine: Access to information related with centers for transplant, types of transplant, regulations, organ donation and number of cases at national level (in Spanish). www.incucai.gov.ar/ institucional/.

118 National Health Service (UK) Blood and Transplant Organisation: Organ donation web site with details of latest news on organ donation and UK statistics on an annual and regional basis. www. organ donation.nhs.uk/ukt/.

119 Brasile L, Green E, Haisch C: Ex vivo resuscitation of kidneys after postmortem warm ischemia. ASAIO J 1997;43:M427-430.

120 Brasile L, Stubenitsky B, Booster M, Green E, Haisch C, Kootstra G: Application of exsanguineous metabolic support to human kidneys. Transplant Proc 2001;33:964-965.

121 Vogel T, Brockmann JG, Friend PJ: Ex-vivo normothermic liver perfusion: an update. Curr Opin Organ Transplant 2010;15(2):167-172.

122 Brockmann J, Reddy S, Coussios C, Pigott D, Guirriero D, Hughes D, Morovat A, Roy D, Winter L, Friend PJ: Normothermic perfusion: a new paradigm for organ preservation. Ann Surg 2009;250:1-6.

123 Raeburn CD, Zimmerman MA, Arya J, Barsness $\mathrm{K}$, Harken AH: Ischemic preconditioning: fact or fantasy? J Card Surg 2002;17:536-542.

124 Koti RS, Seifalian AM, Davidson BR: Protection of the liver by ischemic preconditioning: a review of mechanisms and clinical applications. Dig Surg 2003;20:383-396.

125 Tapuria N, Junnarkar SP, Dutt N, Abu-Amara M, Fuller B, Seifalian AM, Davidson BR: Effect of remote ischemic preconditioning on hepatic microcirculation and function in a rat model of hepatic ischemia reperfusion injury. HPB (Oxford) 2009;11:108-117.

126 Compagnon P, Lindell S, Ametani MS, Gilligan B, Wang HB, D'Alessandro AM, Southard $\mathrm{JH}$, Mangino MJ: Ischemic preconditioning and liver tolerance to warm or cold ischemia: experimental studies in large animals. Transplantation 2005;79:1393-1400.

127 Mediavilla MG, Krapp A, Carrillo N, Rodrıguez JV, Tiribelli C, Guibert E: Efficient cold transfection of pea ferredoxin-NADP(H) oxidoreductase into rat hepatocytes. J Gene Med 2006;8:306-313.

128 Henry SD, van der Wegen P, Metselaar HJ, Scholte BJ, Tilanus HW, van der Laan LJW: Hydroxyethyl starch-based preservation solutions enhance gene therapy vector delivery under hypothermic conditions. Liver Transpl 2008;14:1708-1717.
129 Ritter T, Kupiec-Weglinski JW: Gene therapy for the prevention of ischemia/reperfusion injury in organ transplantation. Curr Gene Ther 2005; 5:101-109.

130 Ma J, Lau CK, Obed A, Dada A, Doenecke A, Fan ST, Schlitt HJ, Tsui TY: A cell penetrating heme oxygenase protein protects heart graft against ischemia/reperfusion injury. Gene Ther 2009;16:320-328.

131 Fahy GM, Wowk B, Wu J: Cryopreservation of complex systems: the missing link in the regenerative medicine supply chain. Rejuvenation Res 2006;9:279-291.

132 Pegg DE: The relevance of ice crystal formation for the cryopreservation of tissues and organs. Cryobiology 2010;60(3 suppl):S36-44.

133 Arav A, Gavish Z, Elami A, Natan Y, Revel A, Silber S, Gosden RG, Patrizio P: Ovarian function 6 years after cryopreservation and transplantation of whole sheep ovaries. Reprod Biomed Online 2010;20:48-52.

134 Gavish Z, Ben-Haim M, Arav A: Cryopreservation of whole murine and porcine livers. Rejuvenation Res 2008;11:765-772.

135 Song YC, Khirabadi BS, Lightfoot F, Brockbank KG, Taylor MJ: Vitreous cryopreservation maintains the function of vascular grafts. Nat Biotechnol 2000;18:296-299.

136 Fuller BJ, Paynter SJ: Cryopreservation of mammalian embryos. Methods Mol Biol 2007;368: 325-339.

137 Baicu S, Taylor MJ, Chen Z, Rabin Y: Cryopreservation of carotid artery segments via vitrification subject to marginal thermal conditions: correlation of freezing visualization with functional recovery. Cryobiology 2008;57:1-8.

138 Nakao A, Sugimoto R, Billiar TR, McCurry KR: Therapeutic antioxidant medical gas. J Clin Biochem Nutr 2009;44:1-13.

139 Kaizu T, Ikeda A, Nakao A, Tsung A, Toyokawa H, Ueki S, Geller DA, Murase N: Protection of transplant-induced hepatic ischemia/reperfusion injury with carbon monoxide via MEK/ERK1/2 pathway downregulation. Am J Physiol Gastrointest Liver Physiol 2008;294:G236-G244.

140 Neto, JS, Nakao A, Kimizuka K, Romanosky JA, Stolz DB, Uchiyama T, Nalesnik MA, Otterbein LE, Murase N: Protection of transplant-induced renal ischemia-reperfusion injury with carbon monoxide. Am J Physiol Renal Physiol 2004;287: F979-F989.

141 Motterlini R, Otterbein LE: The therapeutic potential of carbon monoxide. Nat Rev Drug Discovery 2010;9:728-743.

142 Musameh MD, Green CJ, Mann BE, Fuller BJ Motterlini R: Improved myocardial function after cold storage with preservation solution supplemented with a carbon monoxide-releasing molecule (CORM-3). J.Heart Lung Transplant 2007;26:1192-1198.

143 Sandouka A, Fuller BJ, Mann BE, Green CJ, Foresti R, Motterlini R: Treatment with CO-RMs during cold storage improves renal function at reperfusion. Kidney Int 2006;69:239-247.

144 Pizarro MD, Rodriguez JV, Mamprin ME, Fuller BJ, Mann BE, Motterlini R, Guibert EE: Protective effects of a carbon monoxide-releasing molecule (CORM-3) during hepatic cold preservation. Cryobiology 2009;58:248-255.

145 Theruvath TP, Zhong Z, Currin RT, Ramshesh VK, Lemasters JJ. Endothelial nitric oxide synthase protects transplantated mouse livers against storage/reperfusion injury: role of vasodilatory and innate immunity pathways. Transplant Proc 2006;38:3351-3357. 
146 Johansen D, Ytrehus K, Baxter GF: Exogenous hydrogen sulfide $(\mathrm{H} 2 \mathrm{~S})$ protects against regional myocardial ischemia-reperfusion injury-Evidence for a role of K ATP channels. Basic Res Cardiol 2006;101:53-60.

147 Le Moine O, Louis H, Demols A, Desalle F, De moor F, Quertinmont E, Goldman M, Devière J: Cold liver ischemia-reperfusion injury critically depends on liver T cells and is improved by donor pretreatment with interleukin 10 in mice. Hepatology 2000;31:1266-1274.

148 Ke B, Shen XD, Tsuchihashi S, Gao F, Araujo JA, Busuttil RW, Ritter T, Kupiec-Weglinski JW: Viral interleukin-10 gene transfer prevents liver ischemia-reperfusion injury: Toll-like receptor-4 and heme oxygenase-1 signaling in innate an adaptive immunity. Hum Gene Ther 2007;18 355-366.
149 Ke B, Shen XD, Lassman CR, Gao F, Busuttil RW, Kupiec-Weglinski JW: Cytoprotective and antiapoptotic effects of IL-13 in hepatic cold ischemia/reperfusion injury are heme oxygenase-1 dependent. Am J Transplant 2003;3:1076-1082.

50 Ambiru S, Uryuhara K, Talpe S, Dehoux JP, Jacobbi L, Murphy CJ, McAnulty JF, Gianello P: Improved survival of orthotopic liver allograft in swine by addition of trophic factors to University of Wisconsin solution. Transplantation 2004;27; 77:302-319.

151 McAnulty JF, Reid TW, Waller KR, Murphy CJ: Successful six-day kidney preservation using trophic factor supplemented media and simple cold storage. Am J Transplant 2002;2:712-718.

152 Tögel F, Hu Z, Weiss K, Isaac J, Lange C, Westenfelder C: Administered mesenchymal stem cells protect against ischemic acute renal failure through differentiation-independent mechanisms. Am J Physiol Renal Physiol 2005;289:F31-F42.
153 Parekkadan B, van Poll D, Suganuma K, Carter EA, Berthiaume F, Tilles AW, Yarmush ML: Mesenchymal stem cell-derived molecules reverse fulminant hepatic failure. PLoS ONE 2007;2:e941.

154 Mylotte LA, Duffy AM, Murphy M, O’Brien T, Samali A, Barry F, Szegezdi E: Metabolic flexibility permits mesenchymal stem cell survival in an ischemic environment. Stem Cells 2008;26:13251336.

155 Cherkashina DV, Semenchenko O, Grischuk V, Fuller B, Petrenko AU: Supplementation with fetal-specific factors ameliorates oxidative liver damage during hypothermic storage and reperfusion in a rat model. Cell Preserv Technol 2005;3:201-210.

156 Cherkashina DV, Tkacheva EN, Semenchenko OA, Somov AY, Fuller BJ, Petrenko AY: Pretreatment with fetal-specific factors positively affects rat liver metabolic activity after short-term cold storage. Cryobiology 2006;53:435-436. 